Center for Business and Industrial Marketing Academic Workshop, Atlanta, 2006

\title{
How Can Economic Sociology Help Business Relationship Management?
}

\section{Article proposed for \\ the Special Workshop Issue of the Journal of Business and \\ Industrial Marketing}

\section{Tibor MANDJÁK}

Professor of Marketing

Corvinus University of Budapest and

Bordeaux Business School

680, cours de la Libération, 33405 Talence Cedex France

Phone: 33-556-84-2228

Fax: 33-556-84-5500

Email: tibor.mandjak@bordeaux-bs.edu

\section{Zoltán SZÁNTÓ}

Professor of Sociology

Corvinus University of Budapest

Affiliated Researcher

Bordeaux Business School

1093 Budapest, Fővám tér 8.

Phone: ++ $361482-5232$

Fax: ++ $361482-5226$

E-mail: zoltan.szanto@uni-corvinus.hu

Note: the research is part of a research program financed by the Hungarian Research Fund (OTKA) number KGJ 48560 


\section{Structured abstract}

\section{How can economic sociology help business relationship management?}

Tibor Mandják and Zoltán Szántó

Conceptual paper

\section{Purpose}

By analyzing organizations as social actors and business relationships as social relationships, sociology can improve business relationship management.

\section{Design/methodology/approach}

A business relationship is an interactive exchange between two organizations embedded in a network of business connections. We review theories of social actions and social actors and the concepts of economic field and embeddedness to illustrate some social dimensions of business relationships.

\section{Findings}

Social action and social actor theories emphasize: (1) that co-operation is always encumbered with conflicts; (2) that consciousness about the relationship is fundamental for both strongly and weakly structured actors; and (3) that actors (people involved in a business relationship) always have some freedom of maneuver. The concept of economic field underscores the specificity of each business relationship and the critical need for concrete analysis. The concept of embeddedness highlights that no business relationship is possible without personal bonds.

\section{Research limitations/implications}

There are the first results of a deeper and broader research directed towards a conceptual model of business relationship management.

\section{Practical implications}

The paper can help managers to analyze more deeply the social dimensions of business relations with both suppliers and buyers. Consciousness, the ongoing presence of conflicts, the unavoidable role of personal bonds, and interactivity are always relevant in business relationship management.

\section{Originality/value}


This paper integrates sociological and business marketing approaches. We apply essential sociological theories and concepts to business relationship management.

Key words: business relationship management, sociology, consciousness, embeddedness, social actor, actor bonds 
Some years ago, management guru Peter Drucker expressed a clear vision of our age. He emphasized that "the center of a modern society, economy and community is not technology. It is not information. It is not productivity. The center of modern society is the managed institution. The managed institution is society's way of getting things done these days. And management is the specific tool, the specific function, the specific instrument, to make institutions capable of producing results" (Drucker 1999:46). Results mean that the organization is able to provide what others, its customers, in a broad sense, expect from it. "The task and responsibility of management are all those internal or external factors that have an influence on the performance and result of the organization independent of whether the management is capable of controlling those factors or not" (Drucker 1999:46).

As business relationships and business networks are naturally among factors which affect performance, we can formulate our basic question as follows. What is the implication for business relationship management if we consider the organization as a social actor? In this paper we apply some sociological theories to better understand the problem. We present several examples of how economic sociology can help in managing business relationships. This paper is perhaps an early bird. It tries to bring together the business marketing and economic sociological approaches. It seems quite natural that these two fields of science have a lot to say to each other. A dialogue between economic sociology and inter-organizational marketing can doubtlessly be fertile.

This paper is organized as follows: first we present some fundamental constructs of economic sociology. Then we discuss the main difficulties of business relationships management. The paper concludes with some answers to the question in the title: how can economic sociology help business relationship management?

\section{Economic sociology}

Sociology in a general sense means a science about the relations between the individual and the society. More precisely sociology deals with the interactions between them (Giddens 1993). Sociology is at the same time both a theoretical and an empirical science, using theories, concepts, and empirical data together. In the sociological approach phenomena are analyzed together with their history. Based on empirical data, sociology is able to show many hidden faces of society. Social relationships, for instance, stretch between people, but we 
cannot normally see these relationships. Only some consequences of their existence are directly visible or observable. Theories of social relationships and of social action can help to understand this hidden world.

Economic sociology means the application of the sociological perspective to economic phenomena. A more sophisticated definition states that economic sociology is "the application of the frames of reference, variables, and explanatory models of sociology to that complex of activities concerned with the production, distribution, exchange, and consumption of scarce goods and services" (Smelser and Swedberg 1994:3). Individual and collective interactions, institutions, social control mechanisms (sanctions, norms, values), social networks, as well as the gender, cultural, international and ecological context are the most important fields of investigation for economic sociology. Granovetter and Swedberg (2001) identify three fundamental principles of economic sociology as follows:

"1. Economic action is a form of social action. 2. Economic action is socially situated or embedded. 3. Economic institutions are social constructions" (Granovetter and Swedberg 2001:8). The next subsections briefly review some major sociological theories that describe social actors and their actions, motivations and embeddedness.

\section{Theories of social actions and social actors}

In Economy and Society, Max Weber (1914) defined how economic action is a particular form of social action and made clear differences between the sociological and economic approaches to economic action. Sociology looks at the actor as having her own habits, material and ideal interests, and emotions. In the action, the actor intends to do something and considers other actors as well. There are two differences between social action in general and economic social action in particular. In an economic social action the actor has mainly, but not only, a material interest, and the actor's main goal is utility. The deep difference between sociology and economic theory is manifested here because in economics the actor has only her interests, mainly material, and her unique goal is utility without any regard for other actors (Swedberg 2001).

Based on Max Weber's classical definition we talk about social relationships, if the behavior of many participants is mutually adjusted to each other according to its intellectual content, their behavior is governed by this mutual adjustment. So the social relationship in its entirety 
means a chance that the action (according to its sense) can take place as a social action (Weber 1987:54). Whether this chance is realized or not depends on the judgment of the participants regarding the relationship and on action based on that judgment. According to Weber's sequence of ideas, the participants see the relationship from their own point of view and it is the task of the "interpretative sociology" to explore these various viewpoints (Swedberg 2003). As long as the participants make a decision to enter a mutual relationship with each other, then the social relationship comes into being.

According to the theory of social action, society is composed of social relationships between social actors (Touraine 1973). A social relationship may be defined as co-operation between actors encumbered with conflicts, the purpose of which is to create something jointly. This something is to be interpreted very widely, and the co-operation encumbered with conflicts may be aimed at the creation of a product, as well as a service, such as the organization of the life of a community.

From this perspective we now examine the social actor, what he does in a social relationship and what his motivations are to do it.

The social actor in this context is to be interpreted as a theatrical metaphor (Crozier and Friedberg 1977), i.e. it is such an actor who has many parts and who does not only play the part of the written character, but interprets it at the same time. She always has some kind of individual freedom in the realization of the role, and the role can never entirely determine her way of acting (Bernoux 1999). The social actor is determined by the social relationship in which she takes part. The social actor can be an individual, or an organization like a company. Because co-operating actors face different situations, conflicts are naturally concomitant of social relationships. The social actor may be strongly or weakly structured depending on whether he co-operates in the creation of the joint target or not, on the one hand, and whether he is able to influence the method and direction of co-operation, on the other hand. In other words, the position of a social actor may be regarded as strong or weak depending on the extent to which he can choose his place in co-operation and the extent to which he can protect himself in conflicts (Quivy and Van Campenhoudt 2002).

During both co-operation and the resolution of conflicts realized in the framework of social relationships, the actors mutually influence each other. According to Georg Simmel (1908) it is this very mutual interaction that is the essence of social relationships. During interaction parties mutually influence each other, and these interactions build up the society (Lallement 
2004). Taking into account Simmel's interaction theory, market exchanges are social relationships, too, since they meet the definition of social mutuality (Chantelat 2002).

According to the theory of social action, the co-operation realized in the relationship or the arising conflicts have more than one cause (Crozier and Friedberg 1977, Bernoux 2004). Social actors engage each other if, in their judgment, the co-operation being formed in the framework of the relationship enables them to get access to the assets that they need, and if they possess such abilities or assets that are essential for the partner. It is important for them to implement the particular social relationship, and they are cognizant of the rules of the game of the co-operation to be created in the relationship. Last but not least, they consider whether the efforts necessary for the joint action realized by the relationship are acceptable (Quivy and Van Campenhoudt 2002).

Co-operation is, however, also the source of conflicts. The decisive question is social actors' ability to forbear conflicts. On the one hand, forbearance depends on whether they are able to comprehend and anticipate that conflicts are naturally concomitant with co-operation. It is an important issue how they perceive the rules of the game of the relationship and whether they can imagine changing the rules. The ability to resist conflicts largely depends on how much social actors endeavor to secure their own freedom of movement within the relationship. Lastly, it is also of great significance to what extent they are inclined to put pressure on their partners with their assets (Quivy and Van Campenhoudt 2002).

Simmel emphasizes that social actors are not only connected through direct interactions, but "they are connected with others through the framework of interactions" (Simmel 1908, quoted by Bernoux 2004:117). Simmel (1908) extended the analysis of interactions between two actors by elaborating on how they affect the activity of others. When examining the social effects of competition, he introduced the term tertius gaudens, the essence of which is that the winner and the beneficiary of the interaction between the two actors is a third party. The actor may benefit from the competition between $\mathrm{B}$ and $\mathrm{C}$, because he can sell to or buy from either or both on advantageous terms. Swedberg (2003) quotes one of Simmel's beautiful and thought-provoking statements. "Innumerable times [competition] achieves what usually only love can do: the divination of the innermost wishes of the other, even before he becomes aware of them. Antagonistic tension with his competitor sharpens the businessman's sensitivity to the tendencies of the public, even to the point of clairvoyance, in respect to future changes in he public's tastes, fashions, interests" (Simmel 1908, quoted by Swedberg 2003:22). 
Simmel's beautiful thoughts guide us to a concrete understanding of social actors' economic actions in each particular industry or, using the expression of Pierre Bourdieu, economic field.

\section{Concepts of economic field and embeddedness}

In Pierre Bourdieu's view, the economic actor always exists and acts in a concrete economic field (champ économique). In case of the company as an economic actor, the economic field basically corresponds to the branch of industry of which the company is a member. Each economic field has been created and structured in historical and social context. Each economic field has its own characteristic system of power relations, which is a function of the capital intensity of the participating companies. More precisely, the power relations within the economic field are created depending on how the different types of capital are distributed between the companies involved.

According to Bourdieu's theory (2000a), the company possesses different types of capital, and the quantity and combination thereof define the strength of the company. Financial, cultural, commercial, social and symbolic capital represent the most important types of capital. Cultural capital is composed of several parts, such as technological capital, legal capital, and organizational capital. Commercial capital comprises the company's sales staff and its activity. According to Bourdieu (2000a) social capital is the totality of the mobile capital (financial resources or information) that the company may mobilize through its network in order to gain a competitive advantage or to increase the return on its investments. "Even if we do not question the efficiency of the network (or that of social capital, to put it a better way) in the economic field, we must mention that the practice of the economic actors and the strength of the network mobilized by them, which should be defined as the size of the social capital, if we want to be more precise, primarily depend on the role occupied by the actors in this structured micro-cosmos of the economic field" (Bourdieu 2000a: 242-43). According to Bourdieu's interpretation, these types of capital constitute strategic market assets.

In the economic field interpreted in this way, economic rationality for the actor means the intersections of the scope of socially possible (i.e. created) actions and the just-as-socially created structures and power relations of the economic field (Bourdieu 2000a). Following Giddens' way of thinking (1984), reciprocity and structure are not opposites. The relationship between them is mutual dependence; they mutually affect each other. The structure is, on one 
hand, the result of social actions, and on the other hand, it is also the result of how these social actions are interlinked and structured (Bernoux 2004).

The examination of third parties' influence, of social capital, and of the role of business networks takes us to the elaboration of the issues connected to the social embeddedness of economic actions and institutions.

The sociological spirit teaches that economic action is influenced by others and that the actor is not isolated but embedded in relationships with others. Economic sociology emphasizes the key role of the personal network in the process of embeddedness. Moreover, economic institutions are historically and socially constructed and developed, rather than given, and networks are very important in their formation, as Granovetter and McGuire (1998) demonstrate in their analysis of the origins of the American electrical utility industry at the end of $19^{\text {th }}$ century. "Networks may play a crucial role especially at an early stage in the formation of an economic institution; once the development is 'locked in,' however, their strategic importance decline." (Granovetter and Swedberg 2001:18)

The New Economic Sociology, born in the 1980s in North America, strongly emphasizes the role of embeddedness and the socially constructed nature of institutions. Analyzing the history of economic sociology, Steiner (1999) argues that the concept of social action and the question of institutions were always at the heart of this discipline, whether one speaks of old (classical) or new economic sociology.

By embeddedness, Granovetter (1990) means that economic action, results, and institutions are influenced by the actors' personal relationships and by the entire structure of the network of relationships. On the other hand, an actor's attempts at purposive action are "embedded in concrete, ongoing systems of social relations" (Granovetter 1985:487). The author distinguishes between relational and structural embeddedness. The essence of structural embeddedness is that all bilateral economic relationships are, at the same time, parts of a more comprehensive social network of connections. Relational embeddedness, which means economic actors' personal network of relationships, usually has a direct influence on the relationship, whereas structural embeddedness has an indirect effect (Granovetter 1990).

According to Granovetter's theory the secret of maintaining exchanges and their economic efficiency lies in social actors' ability to create personal relationships. As a result of the ability to create personal relationships, personal relationships are continuous, stable and emotionally substantiated. This ability is the basis of exchanges and this ability, which creates trust in personal relationships, is indispensable for the exchange (Chantelat 2000). One of the 
important roles of the network of relationships is to reduce the losses stemming from a possible dishonest behavior or from a lack of trust (Steiner 1999).

\section{Management of business relationship}

Business relations are everyday phenomena of business life, and their management involves a continuous daily task. However, if we take a closer look at the relationship established with a customer or a supplier, then we encounter an ever-changing exchange, which includes a great number of parties and a great variety of activities - e.g. purchase and sale, delivery, payment, negotiations - bringing together different views and interests, encumbered with conflicts in many cases, and also having some kind of history.

Resource-based theory (e.g. Barney 1991, Grant 1995) conceptualizes business relations as one of the basic energy resources and an important asset of corporations and businesses. A company gets access to necessary products and services, income, information, and innovations through relationships. The business is connected to its environment through relationships. System theory (e.g. Ackoff 1971) directs our attention to the extreme importance of the mutual connection between a system and its environment. In this interpretation, business relationships play a fundamental role in connecting the organization with its environment in both directions, to its suppliers and its buyers. Quoting the wellknown expression of Hakansson and Snehota (1989), none of the companies are islands, none can exist without business relations. The company's system of business relations constitutes a portfolio of relationships, or a corporate network (Zolkiewski and Turnbull 2002), and represents a key strategic concern.

A business relationship involves a simultaneous possibility and challenge for the participants (Hakansson and Snehota 2002). The participants in the relationship may either recognize the possibilities of deeper investment in the relationship or realize its limits. Efficient management requires the participants to make a decision about the future of the relationship. Interaction and mutual dependence make business relations dynamic and complex and make the management of relations significantly more difficult. The management of business relations becomes especially complicated because an event or development external to the relationship, e.g., , a change in import regulation, natural disaster, strike, or offer from a new competitor, may substantially influence the action of the participants. This change in behavior 
may have either a positive or negative effect on the exchange processes in the relationship and its results.

The business relationship is an economic and social phenomenon, and it must be treated accordingly. Business relationships always have economic and social dimensions. The economic dimension is utility. In practice, or at least in principle, this utility can be expressed in terms of figures. The social dimension means behavior or changes in behavior. Both dimensions are constituted by different components.

The management of the economic components of business relations is rapidly developing. The pace of change is indicated by the widespread adoption of special software, customer relationship management (CRM) systems, intended to automate and optimize customer relationships. However, the grave difficulties arising during their use and application (e.g. Narus 2005) call attention to the role of the social components of business relations. The management of the sociological components of business relations has been worked out to a much lesser degree. It is all the more important to develop the joint consideration of the economic and sociological components.

To synthesize our literature review, we define the business relationship as an interactive exchange between two companies embedded into a network of business connections. To be more specific, it is not entire companies that get in touch with each other; it is only groups of people at each company who constitute the relationship. The business relationship actually involves the relationship between the two groups. Business relations have, naturally, their economic and social components, antecedents, and effects. We interpret the social components broadly and includ the cultural, cognitive, and political elements as well as the personal relationships. How do we manage business relations? In what ways can sociological theories help?

\section{How can economic sociology help?}

Sociology in general and economic sociology in particular can help managers in different ways. Theories give a broader view of phenomena; they may reveal new or hidden issues. Theories facilitate a deeper understanding of reality. Last but not least they can offer a new framework of analysis. The usefulness of any theory depends on the application. In applying a 
theory, we must pay attention to its abstraction level and to its assumptions. Unwarranted direct application of theory may be ineffective or even dangerous.

If we consider a business relationship as an economic and social phenomenon and want to deal with it accordingly, what we can learn from sociology?

\section{Some lessons from social action and social actor theory}

Social actions are realized in social relationships by social actors. In social relationships, actors mutually adjust their behavior with each other. Mutual adjustment means that actors are naturally and always influenced by the other partners. Each can make her own decision to establish, deepen, or terminate a social relationship. These decisions are based on each actor's own judgment and perception of the relationship. Whenever a relationship exists, these decisions are always reflected by, or elicit reaction from, the partner.

The relationship itself is an opportunity for more actions. This chance or possibility must be exercised by the actors. Willingness to participate depends on how actors consider the relationship.

A social relationship always means an opportunity for co-operation to create something jointly but encumbered with conflict.

Business relationships are a special form of social relationship. Their distinguishing feature is the fact that a business relationship is created, maintained, developed, or terminated for an economic goal, to obtain necessary resources. Value for both partners is jointly created. Value means simply the resources needed by the partners and exchanged in the business relationship in the form and sequence of different exchange episodes. These resources may be material or immaterial (i.e., utilities) for the buyer and are generally monetary (revenue, cash flow, or profit) for the supplier. Profit and benefit-maximizing behaviors are almost always present in a business relationship. But these relationships are always imbued with social phenomena and behaviors as well, and partners must ask questions about the real goal of each business relationship. What do they want to do in it and with it?

A business relationship is always an opportunity to benefit, but as Hakansson and Snehota (2002) emphasize, the relationship is always a constraint as well. To benefit, partners have to take actions and to realize different exchanges. However co-operation and conflicts emerge simultaneously between actors involved in a business relationship. There is no business relationship without conflicts. 
Social actors have their own habits, interests and emotions. Interests can be ideal as well as material. Ideal interests take many forms, such as mental, symbolic, or ideological interest. Acting in a social relationship, the actor is determined by the social relationship in which he participates. On the one hand, the social actor plays a role shaped by the relationship. On the other hand, the social actor always has some individual freedom for the interpretation and realization of her role. An actor's freedom in a relationship depends upon the actor's level of structure. A social actor is strongly structured if he both chooses his place in the co-operation and protects himself in the eventual conflicts of the relationship. The first criterion of strong structure means that the actor participates in the creation of a relationship's joint target and in the definition of the methods of cooperation and the rules of mutual governance. The second criterion includes the actor's ability to understand and to anticipate the inherent conflicts of the co-operation, to comprehend the rules of the game, and to accept the idea of changing these rules.

Business relationships are created by two social actors. The actor's natural interests are, of course, economic, but there is always some room for her emotions and immaterial interests as well. In business relationships, actors play the role of either the supplier or the buyer. Even if these roles are sometimes strictly shaped, as in the case of formal bidding, buyer or supplier may still find some room to maneuver. We emphasize the importance both of episodes of social exchange and of organizational memory about the relationship. The latter consists of the history of the relationship and the frozen experiences of it (in organizational artifacts).

To some extent, business relationships have a legal and institutional framework, but power is always an issue between the partners. In theory, business relationships work well if the power situation of the two actors is balanced. Power is commonly associated with the possession of resources. However the basic matter seems to be how the social actors are structured. The more the buyer and the supplier work together on the joint target and the rules of the cooperation, the more the relationship may be balanced. Even in the closest business relationship, a real, omnipresent danger is different perceptions of the rules of the game and of intentions to change them.

Some lessons from the concepts of economic field and embeddedness 
Business relationships can be woven differently in each economic field. Partners' behavior with each other may be specific to the economic field. Third parties who can influence or benefit from the business relationship, Simmel's tertius gaudens, also differ by economic field. To understand business relationships it is necessary to make a deep historical and structural analysis of the economic field where the relationships exist. It is complicated and risky to transfer directly the knowledge and practice (even "best practice") of the management of business relationships in one economic field to another economic field.

In a business relationship, the various actions of the people involved in the two companies are, indeed, adjusted within the relationship. This adjustment really means the realization of the exchange episodes fulfilled in the relationship, in the course of which the problems of mutual adaptation and organizational learning arise. It is, in fact, the interactive nature of the relationship that ensures or demands the mutual adjustment to some extent. For both parties, the expressed aim is to reach their economic targets. The expressed goal, however, does not mean that we encounter only rational, target-oriented actions in business relationships. At the same time, the business relationship always involves a co-operational possibility between two companies, the realization of which depends on what perceptions or images the involved parties have about the relationship. Thus in an economic sociological sense, a business relationship may be regarded as a type of social relationship.

The embeddedness of business relationships is realized not only in the relationship between those involved (personal bonds) but also emerges through activities (activity links) and resources (resource ties). The structure of the given business network means the structural aspect of embeddedness. We can grasp the four basic dimensions of embeddedness in the case of a business relationship, namely the cognitive, cultural, structural and political aspects.

With respect to the cognitive aspect, the relevant features are the mental models with which the parties judge the relationship and their expectations regarding the relationship. A further important issue is the management of uncertainty: on the one hand, the business relationship may reduce market uncertainty, because "I know my partner"; yet at the same time the relationship erects a barrier during decision-making because "I must take into consideration uncertainty about my partner's reactions."

With respect to cultural elements, differences appear in business relationships. The cultural distance between partners must be handled, but cultural elements are also present in the form of similarities or differences between the organizational structures of the two partners. 
Embeddedness theory emphasizes the key role of personal network in the process of economic actions. Whether we consider the action itself, the decision about the action, or the actor's perception of the involvement of third parties, the influence of the network is always possible, often important, and sometimes decisive. This influence occurs through personal relationships, which is relational embeddedness. Structural embeddedness means that all bilateral economic relationships are, at the same time, parts of a more comprehensive social network of connections.

Business relationships are always embedded in a business network, which takes the part of a broader social network. Personal relationships (actor bonds) play a very important role in a different sense and way. From the point of view of the business relationship and the actors (individuals) involved, there can be at least four types of personal relations. First, the actors may have a personal acquaintance with the partner's involved people. This acquaintance is mainly the result of the social exchange episodes of the business relationship. The second type of personal relations is with colleagues at the organization level. The third type involves personal relations with other business actors. Relations other than professional relations, e.g., shared family or mutual friends, constitute the fourth type. In fact these circles are interrelated.

Thus, the embeddedness of business relationships is realized not only in the relationship between those involved (personal bonds) but also comes into being through activities (activity links) and resources (resource ties). The structure of the given business network means the structural aspect of embeddedness.

\section{Conclusion}

Economic sociology can help by its emphasis on social analysis. Analysis of atomized human action is unlikely to bear fruit. The social actor may be strongly or weakly structured. His actions are "embedded in concrete, ongoing systems of social relations" (Granovetter 1985:487).

The economic actor always exists and acts in a concrete economic field. Each economic field has been created and structured in historical and social context. Each economic field has its own characteristic power relation system. This power system is depending on how the different types of capital are distributed among the companies involved. 
Economic sociology can help by considering the complexity of business relationship. The management of business relationships is a collective activity. Its collective nature manifests itself in several contexts. The business relationship itself involves a relationship between two groups. This relationship changes as a function of the group perception of the parties involved. In the management of business relationships, it seems necessary to take into account the economic psychological and social psychological peculiarities of social relationships in addition to the classical, profit-oriented, and cost-cutting approach of economic management. In the management of business relationships, economic factors without doubt play an important role. But efforts to make the relationship efficient are always made in light of and as a function of perceptions.

The purpose of our research is to develop a conceptual model that can improve management of business relationships. This conceptual model could take into consideration the external and internal regulations of the relationship and the interpretations and actions of those involved in the relationship. Our conceptual model has been developed with the confidence that deeper understanding of the complexity of business relationships and consistent reflection on this complexity may contribute to the more successful management of relationships.

Our model, first summarized in a research paper of the Bordeaux Business School, is now presented in this Special Issue of the Journal of Business and Industrial Marketing dedicated to questions of mutual interst in business marketing and sociology.

To conclude, the most important issue is that management of business relationship involves human action. Technology can facilitate and increase efficiency but can never totally replace the human being, the social actor, in business. 


\section{References}

Ackoff, R.L. (1971): Towards a system of systems concepts. Management Science, Volume 17. No.11: 661-671

Barney, J.B. (1991): Firm resources and sustained competitive advantage. Journal of Management, Volume 17. No.1: 99-120

Bernoux, P. (2004) : Sociologie du changement dans les entreprises et les organisations. Paris, Éditions du Seuil

Bernoux, P. (1999) : La sociologie des entreprises. $2^{\mathrm{e}}$ édition, Paris, Éditions du Seuil Bourdieu, P. (2000a) : Principes d'une anthropologie économique. pp. 233-270 In : Bourdieu, P. (2000b) : Les structures sociales de l'économie. Paris, Seuil

Bourdieu, P. (2000b) : Les structures sociales de l'économie. Paris, Seuil

Cabin, P. - Dortier, J.-F. (2004) (eds.): La sociologie, Histoire et idées. Paris, Éditions Sciences Humaines

Chantelat, P. (2002) : La Nouvelle Sociologie Économique et le lien marchand : des relations personnelles à l'impersonnalité des relations. In : Revue Française de Sociologie, Volume 43, Numéro 3, Juillet Septembre : 521-556

Crozier, M. - Friedberg, E. (1977) : L'acteur et le système, Les contraintes de l'action collective. Paris, Éditions du Seuil

Drucker, P. (1999): L'avenir du management. Paris, Éditions Village Mondial

Friedland, R. - Robertson, A.F. (1990) (eds.): Beyond the marketplace: Rethinking economy and society. New York, Aldine de Gruyter

Giddens, A. (1993): Sociology. Second edition, Cambridge, Polity Press

Giddens, A. (1984): The constitution of society. Oxford, Basil Blackwell

Granovetter, M. (1990): The old and the new economic sociology: A history and an agenda. pp. 95-112 In: Friedland, R. - Robertson, A.F. (1990) (eds.): Beyond the marketplace: Rethinking economy and society. New York, Aldine de Gruyter

Granovetter, M. (1985): Economic action and social structure: The problem of embeddedness. American Journal of Sociology 91: 481-510.

Granovetter, M. - McGuire (1998): The making of an industry: Electricity in the United States. pp. 147 - 173 In Callon, M. (1998) (ed.): The laws of the markets. London, Blackwell

Granovetter, M. - Swedberg, R. (2001): The sociology of economic life. Second edition. Boulder, Westview Press

Grant, R.M. (1995): Contemporary strategy analysis, Concepts, techniques, applications. Second edition, Cambridge, Massachusetts, Blackwell Publishers Inc.

Hakansson, H. - Snehota, I. (2002): Marketing in business markets. pp. 513-526 In: Weitz, B.A. - Wensley, R. (2002) (eds.): Handbook of marketing, London, Sage Publications

Hakansson, H. - Snehota, I. (1989): No business is an island: The network concept of business strategy. Scandinavian Journal of Management, Volume 4, No.3: 187 200

Lallement, M. (2004): Georg Simmel : père méconnu de la sociologie interactionniste. In : Cabin, P. - Dortier, J.-F. (2004) (eds.): La sociologie, Histoire et idées. Paris, Éditions Sciences Humaines: 59-66

Narus, J.A. (2005): Connect with your suppliers, A wholesaler-distributor's guide to electronic communications systems. Washington D.C., NAW DREF

Quivy, R. - Van Campenhoudt, L. (2002): Manuel de recherché en sciences sociales. $2^{\mathrm{e}}$ 
édition, Paris, Dunod

Simmel, G. (1908): Soziologie, (Sociology) Leipzig

Smelser, N.J. - Swedberg, R. (1994): The sociological perspective on the economy. pp. 3-26 In Smelser, N.J. - Swedberg, R. (1994) (eds.): The handbook of economic sociology. New York, Princeton University Press

Smelser, N.J. - Swedberg, R. (1994) (eds.): The handbook of economic sociology. New York, Princeton University Press

Steiner, P. (1999): La sociologie économique. Paris, Éditions La Découverte

Swedberg, R. (2001): Max Weber's vision of economic sociology. pp. 77-95 In Granovetter, M. - Swedberg, R. (2001): The sociology of economic life. Second edition. Boulder, Westview Press

Swedberg, R. (2003): Principles of economic sociology. Princeton, Princeton University Press

Touraine, A. (1973): Production de la société. Paris, Éditions du Seuil

Weber, M. (1987): Gazdaság és társadalom, A megértő szociológia alapvonalai 1. Szociológiai kategóriatan. (Economy and society) Budapest, Közgazdasági és Jogi Könyvkiadó (original Weber, M. (1976): Wirtschaft und Gesellschaft, Grundriss der verstehenden Soziologie, 1. Halbband. 5 edition, Tübingen, J.C.B. Mohr

Weitz, B.A. - Wensley, R. (2002) (eds.): Handbook of marketing, London, Sage Publications

Zolkiewski, J. - Turnbull, P. (2002): Do relationship portfolios and networks provide a key to successful relationship management? Journal of Business and Industrial Marketing, Volume 17, No.7: 575-597 